\title{
Challenges of Human Resource Management in the Armed Forces of Ukraine
}

\author{
VITA HALUSHKA \\ National University of Life and Environmental Sciences of Ukraine, \\ 15 Heroiv Oborony, Kyiv, \\ UKRAINE \\ HRYHORII TIKHONOV \\ Command and Staff Institute of the Troops (Forces) Combat Use, \\ National Defense University of Ukraine named after Ivan Chernyakhovsky, \\ 28 Povitroflotskyy avenue, Kyiv, 03049. \\ UKRAINE \\ IVAN TIKHONOV \\ Department of Tactics and Combined Arms Disciplines, \\ Ivan Kozhedub Kharkiv National University of Air (KNAFU), \\ 77/79 Sumskaya street, Kharkiv, 61001. \\ UKRAINE \\ YURII MYKOLENKO \\ Command and Staff Institute of the Troops (Forces) Combat Use, \\ National Defense University of Ukraine named after Ivan Chernyakhovsky, \\ 28 Povitroflotskyy avenue, Kyiv, 03049. \\ UKRAINE

\section{LIUDMYLA DROK} \\ Department of the Military training, \\ National Defense University of Ukraine named after Ivan Chernyakhovsky, \\ 2/32 Aviakonstruktora Antonova street, Kyiv, 03049. \\ UKRAINE
}

\begin{abstract}
The purpose of the article is to identify challenges of human resource management tools in the Armed Forces of Ukraine and develop possible ways to address them in the time of Russia's military aggression against Ukraine and a radical reform of Ukraine's defense sphere. A study of the defense reform implementation has shown that, despite the introduction of new principles and methods of work with military personnel, there are still some shortcomings in human resource management. It is possible to overcome these challenges through the improvement of mechanisms for training, retraining and advanced training of servicemen, certification, rotation and strengthening the monitoring of human resource services. As well this article describes ways to improve management such as planning of personnel administration, improvement of educational methods in military educational institutions, introduction of individual plans into the educational process and retraining / advanced training of personnel. So following these instructions step by step can significantly improve handling of military servants of Ukraine. And finally, it is really important to pay attention on all the details during the war. We proposed a research hypothesis - the problems of insufficiently effective implementation of human resource management in the AF of Ukraine originate from imperfect personnel management, and can be solved by engaging personnel management practices applied in the corporate sector.
\end{abstract}

Key-Words: - human resource management, the Armed Forces of Ukraine, Ukraine, War, Military, Reforms.

Received: June 27, 2021. Revised: December 28, 2021. Accepted: January 19, 2022. Published: January 20, 2022. 


\section{Introduction}

The events of 2014, when the Russian Federation (hereinafter - Russia) annexed Crimea, triggered an armed conflict in the eastern territories of Donetsk and Luhansk regions, demonstrated extremely low combat capability of the Armed Forces of Ukraine (hereinafter - the AF of Ukraine) and their complete unpreparedness to defend territorial integrity of the state. At the beginning of Russian military aggression, the regular number of the AF of Ukraine did not exceed 120 thousand people, while about 5-6 thousand servicemen were combat-ready [1]. Therefore, in 2014, the first steps were taken towards reforming the AF of Ukraine and the first task at that time was to increase the number of troops (forces). The process of reforming the AF of Ukraine was complicated by the actual conduct of hostilities, a significant lack of resources, time and urgent necessity of forming new mechanisms of the state defense capabilities' management. Despite the obstacles, since 2016 the defense reform in Ukraine has become large-scale and planned, systematic workforce reforms have been implemented.

On 12 June 2020, Ukraine was recognized by the NATO North Atlantic Council as a member of NATO Enhanced Capabilities Program. In practice, this means increase of cooperation between Ukraine and the Alliance: expanded access to training programs, exchange of experience and information. Pursuant to the intensification of military cooperation, the present agenda includes the issue of bringing the basic principles of the AF of Ukraine functioning in compliance with the international operation principles of the NATO member states' armed forces, in particular in the field of human resource policy.

Reforming the human resource management system of the AF of Ukraine has been identified as one of the key areas of defense reform in Ukraine. Among the main human resource policy challenges of the security and defense sector, identified in the Strategic Defense Bulletin of Ukraine were the issues of manning the armed forces during mobilization, low professional level of military personnel, insufficient military reserve, problems of transition to all volunteer force recruitment of the armed froces [2]. This management system is aimed at long-term interaction of all employees in order to improve the quality of both goods and services offered by the company, its high productivity and its achievements [15].

Recently, state-building bodies have adopted basic regulations outlining the principles of defense reform, in particular those relating to human resource policy. However, today the main challenge is the development of mechanisms for implementing human resource policy in the AF of Ukraine. The desire to comply with NATO standards necessitates the development of new approaches to human resource management in the defense sector.

It is worth repeating that the beginning of the armed aggression of the Russian Federation against Ukraine and the increase in the size of the army gave impetus to a change in approaches to human resource management. However, today the Armed Forces lag far behind the civilian sector in this respect, as the army still mostly uses a system of negative motivation, and the personnel management system does not adopt the experience and experience of the civil sector [33].

Today's current challenges require informed decisions about force structure requirements, recruitment and retention programs, well-being and staff readiness programs, both from the point of view of the individual and from the point of view of units. Personnel managers must acquire a number of professional and specialized skills to address the above challenges and moderate programs that include both the functions and integration systems of the HR life cycle model [14].

In this article, we proceed from the definition "Military force", which should be understood as a system and related processes that provide a competent person with relevant qualifications, in the right position at a particular time or in other worlds to achieve a balance between " space "(demand side) with" face "(supply side) [16].

Regardless of the strategies for managing their own defense institutions, each nation still needs its own common concept, as well as policies and visions, to manage its own security forces and the people in them. HRM is combined with elements such as resource allocation and logistics to form pillars that support the overall management of the country's defense sector [17].

The purpose of the article is to identify challenges of human resource management tools in the Armed Forces of Ukraine and develop possible ways to address them in the time of Russia's military aggression against Ukraine and a radical reform of Ukraine's defense sphere.

During the preparation of the article, foreign and Ukrainian scientific research on the topic of human resources management in the armed forces was analyzed. In the context of the analysis of foreign experience the researches were analyzed: Patrichi (2015); Narang (2016); Goede (2020); LeMoyne (2004); Stanit, Rizescu (2012); Leonard (2017); Bradley, Mills, Narayanan, Gold, Wirth, Ausink, 
Bennett, McGarvey, Ali, Syme, Williams (2021); Winkler, Shanley, Schank, Crowley, Mattock, Green, Madison, McDonald, Steinberg (1999); Drain, Sampson, Billing, Burley, Linnane, Groeller (2015); Shanley, Winkler (1999); Mcardle, Kehr, Colabatistto (2020); Brading (2020).

Among Ukrainian scientists, the relevant studies were: Bielileskov ("The main problem of our army is limited resources. Official website of the Ministry of Defense of Ukraine"); Krasota, Trakaliuk, Shtanko ("Experience of reforming the human resource management system in the Armed Forces of Ukraine"); Medvid, Polovinkin ("Human resource management system in the Armed Forces of Ukraine: features of development"); Koval ("Improving the state human resourse policy in the Armed Forces of Ukraine"); Gozuvatenko ("Enchancement of the military training and career growth system of the Armed Forces of Ukraine, taking into account the experience of leading countries"); Hetmanchuk, Fakhurdinova ("Ukraine and NATO standards: what has been done during Zelensky's presidency?"); Komisarova ("How close the Ukrainian army is to NATO standards. The Deputy Minister of Defense is responsible"); Berezyns'kyy ("Improving military social standards: what they plan to change"). It is worth paying special attention, firstly, to "The Vision of the General Staff of the Armed Forces of Ukraine for the development of the Armed Forces of Ukraine for the next 10 years" from the Ministry of Defense of Ukraine, and secondly, supported by The International Renaissance Foundation research:). Why are servicemen discharged from the army? Public version. The International Renaissance Foundation. (2021) and Why are servicemen discharged from the army? (2021).

This article describes ways to improve management, such as personnel administration planning, improving training methods in military schools, implementing individual plans in the training process, and retraining / advanced training of Ukrainian army personnel in the context of its institutional and organizational reform.

\section{Analysis of Recent Research and Publications}

Attention to the issue of ensuring effective human resource management of the AF of Ukraine is due to the importance of the human factor in building the defense potential of the state. The issue of transformation of human resource management principles in the $\mathrm{AF}$ of Ukraine is a promising subject of research and has its own specifics. When studying the human resource management system in the armed forces, one should take into account the differences between the military and corporate sector.

Patrichi, analyzing the difference between human resource management in military and nonmilitary organizations, identifies the following shortcomings of the defense sector: lack of flexibility, longer terms for recruitment and recruitment only for the entry level, and not for any level, as in corporate organizations, promotion begins within the system and only rank by rank [3]. However, notes that it is impossible to reject the general principles of human resource management, which must be adapted to the defense sphere, outlines the tasks of human resource management in the armed forces which is a development of a human resource management system capable to provide the necessary training, build an effective structure of the armed forces with proper distribution of specialists according to the specification, motivate servicemen to serve and perform their work properly.

Krasota, Trakaliuk, Shtanko describe the tendencies that determine the impact of the personnel management system of NATO member states on the staffing system of the AF of Ukraine and note that the main resource of the Allied armies is human resource, therefore, the development effective human resource management in the countries of the North Atlantic Treaty is given considerable attention [4].

Narang also notes that the most important resource in an organisation, particularly in the armed forces, is people. According to the researcher, human resource management in the armed forces can be considered in terms of a soft and hard approach. A hard approach sees servicemen as a resource for achieving organizational goals, while a soft approach provides incentives to achieve results [5]. Considering the functions of human resource management in the armed forces, Narang identifies the following subsystems:

1) planning, resource allocation;

2) recruitment and selection;

3) education, training and development;

4) remuneration;

5) relationships with employees.

Goede, considering the subsystems of human resource management in the armed forces, identifies the following: working conditions and the environment; guarantee of social protection and safe workplace; providing opportunities for education 
and training; recognition and awards; regular evaluation of performance [6].

A brief analysis of the achievements of foreign scientists allows us to formulate a conclusion that when planning the human resource management system of the AF of Ukraine it is necessary to take into account the existing general corporate/industrial approaches to the organization of personnel management systems. The implementation of defense reform in Ukraine shows that the formation of human resource management is based on the following trends: the withdrawal from the command-administrative principles and the transition from a nomenclature system to a centralized system of career pursuit. In particular, A. Medvid notes that the functioning of the AF of Ukraine has long been based on the nomenclature approach, when the cumbersome structure of the armed forces did not allow addressing challenges in a timely manner, and the military did not apply an individual approach [7]. This was confirmed by the problems of mobilization deployment of the AF of Ukraine in response to the armed aggression of Russia. According to O. Koval, the first stages of mobilization, conducted in 2014-2015, proved the inefficiency of human resource management and decision-making methods, in particular, regarding the personnel accounting system.

According to O. Hrynenko, the factors that had a negative impact on partial mobilization include the shortcomings of the legal framework, reservation of persons liable for military service the absence of their single state register, the absence of servicemen social security and as a result low performance motivation [8].

Today, the transformation of the human resource management system in the AF of Ukraine is identified as a key area, the main goal of public policy is the professionalization of the $\mathrm{AF}$ of Ukraine. According to O. Koval, manning of the AF of Ukraine with trained and motivated personnel is, among other things, one of the requirements for the defense sphere to comply with NATO criteria [9].

At the same time, if we focus not only on NATO criteria but also on NATO standards, it should be noted that as of January 2021, Ukraine has adopted 292. At the same time, according to experts, the New Europe Center (Ukraine) is an obstacle and challenge to implementing standards. NATO in Ukraine is: "Irrational use of human resources. The increase in time spent on implementing NATO standards is due not only (and perhaps not so much) to the low level of language training, but also to the irrational use of personnel with the appropriate level of language proficiency and the necessary professional training in the process of implementing the standards. This problem is directly related to the lack of change in approaches and transformation of professional culture in the systems of the leadership of the defence forces. There is a slight renewal of staff in the relevant bodies (management positions are mostly held by representatives of the "old cohort"), and the lack of career opportunities for representatives with new approaches, the experience of internships in prestigious educational institutions of NATO member states, proper understanding of how the armed forces of Allies function" [32].

However, despite the generally positive shift in the defense sector reform, in terms of the transformation of the human resource management system, there are some difficulties in reforms implementation, and not all developed personnel administration mechanisms are implemented properly.

For example, G. Gozuvatenko notes that today the management of military career is characterized by a number of shortcomings, including subjectivity in personnel decisions made by commanders, which result in the delay of the promotion of professional servicemen to higher positions in other military units, and vice versa, referral to training of persons with low discipline, in order to "get rid" of their presence in the unit [10].

Thus, the purpose of our study is to identify challenges of human resource management in the AF of Ukraine and develop possible ways to address them.

Research hypothesis - the problems of insufficiently effective implementation of human resource management in the $\mathrm{AF}$ of Ukraine originate from imperfect personnel management, and can be solved by engaging personnel management practices applied in the corporate sector.

\section{Presentation of the Main Research Material}

\subsection{Defense Reform Improvements}

In general, it should be noted that the monitoring of the implementation of defense reform in Ukraine testifies to its success. This fact is confirmed by international studies, for example, in the Global Fire Power rating for 2020, Ukraine took $27^{\text {th }}$ place out of 138 countries (last year Ukraine was in $29^{\text {th }}$ place). Such results indicate positive trends in military capacity building [11] 
The state funding for the defense sector is gradually increasing. Thus, in 2020, in accordance with the Law of Ukraine "On the State Budget of Ukraine", expenditures on national security and defense amount to UAH 245.8 billion, which is almost 5.5\% of GDP (including UAH 135.5 billion on defense or $3 \%$ of GDP) [12]. According to NATO member states' standards, defense budget expenditures are divided into the maintenance of the armed forces - 50\%, armaments development expenditures $-30 \%$, troop training expenditures $20 \%$.

According to the Vision of the General Staff of the AF of Ukraine for the development of the AF of Ukraine for the next 10 years, the army should be respected among the population, allies, follow its traditions, be trained, manned with motivated personnel, equipped with modern weapons and military equipment, capable to operate independently and jointly with Ukraine's partners [13]. In turn, this confirms that one of the main priorities of defense reform is the training of servicemen.

Human resource management in the defense sphere, in particular, servicemen training and career management, is an extremely important area of public policy. Human resources services (management) are entrusted with the functions of working with servicemen, planning personnel work, forming a reserve, improving their professional level.

As part of the defense reform, the work of military service recruitment bodies was radically changed - the former military commissariats, which worked mostly using administrative and coercive methods, were transformed into territorial recruitment centers that use corporate recruitment tools.

Measures were also taken to optimize the organizational structure of the human resource services of the AF of Ukraine, in particular, their functions were clarified, and their number was increased; the human resource center of the Land Forces of the AF of Ukraine and the human resource center of the Naval Forces of the AF of Ukraine were established.

A comprehensive military performance evaluation system was introduced. This system involves annual performance evaluation taking into account the results obtained during personnel decision-making. Within the evaluation system, a mechanism for servicemen self-evaluation has also been introduced, and specific criteria for performance evaluation have been developed. An important step towards the optimization of human resource policy was the introduction of a single automated information and analytical system of personnel accounting.

Undoubtedly, the army must be highly professional and unite no less highly motivated and qualified soldiers, the selection of which must be clear and reasoned. Thus, in an effective Armed Forces, the algorithm for selecting professional soldiers should be planned and evaluated. the latter should be based not only on a clear personnel strategy, but also meet the goals of the organization, its strategic mission and vision [18].

Due to the defense reform, a number of initiatives has already been implemented to strengthen public motivation for military service. Thus, the media regularly advertises contract military service. Approaches to the selection of candidates for contract military service have been identified. Such a policy pays off, as the number of people recruited on a contract basis is increasing every year. However, it is too early to talk about a problem-free military-patriotic upbringing of young people. The overall effectiveness of measures to involve individuals in military service remains insufficient.

At the same time, it is necessary to note a number of challenges which arose during the implementation of the human resource management system reform in the AF of Ukraine. These problems are rather basic, as the key one is the low quality of military training. Graduates of military universities are not always ready to put the acquired knowledge to use. There are also problems of poor advanced training of the military.

As it has been mentioned earlier, the problem of a biased assessment of the servicemen performance during their certification also needs to be addressed. There are difficulties in the rotation of servicemen, uncertainty, lack of career growth planning and forecasting.

The human resource management system of the $\mathrm{AF}$ of Ukraine can be represented in the form of a three-block-structure: the strategy of human resource policy, the block of determining the principles of human resource policy and personnel administration (Fig. 1). The stage of defining the strategy of human resource policy is a standardized regulation of human resource management, that is the definition of fundamentals and operation principles and their legitimization in regulatory documents. At the stage of determining the principles of human resource policy tactics, certain principles of decision-making are detailed, specific forms and tools of personnel administration are determined. At the stage of tactical implementation 
of human resource management the actual implementation of assigned personnel administration principles takes place via engagement of certain methods tools.

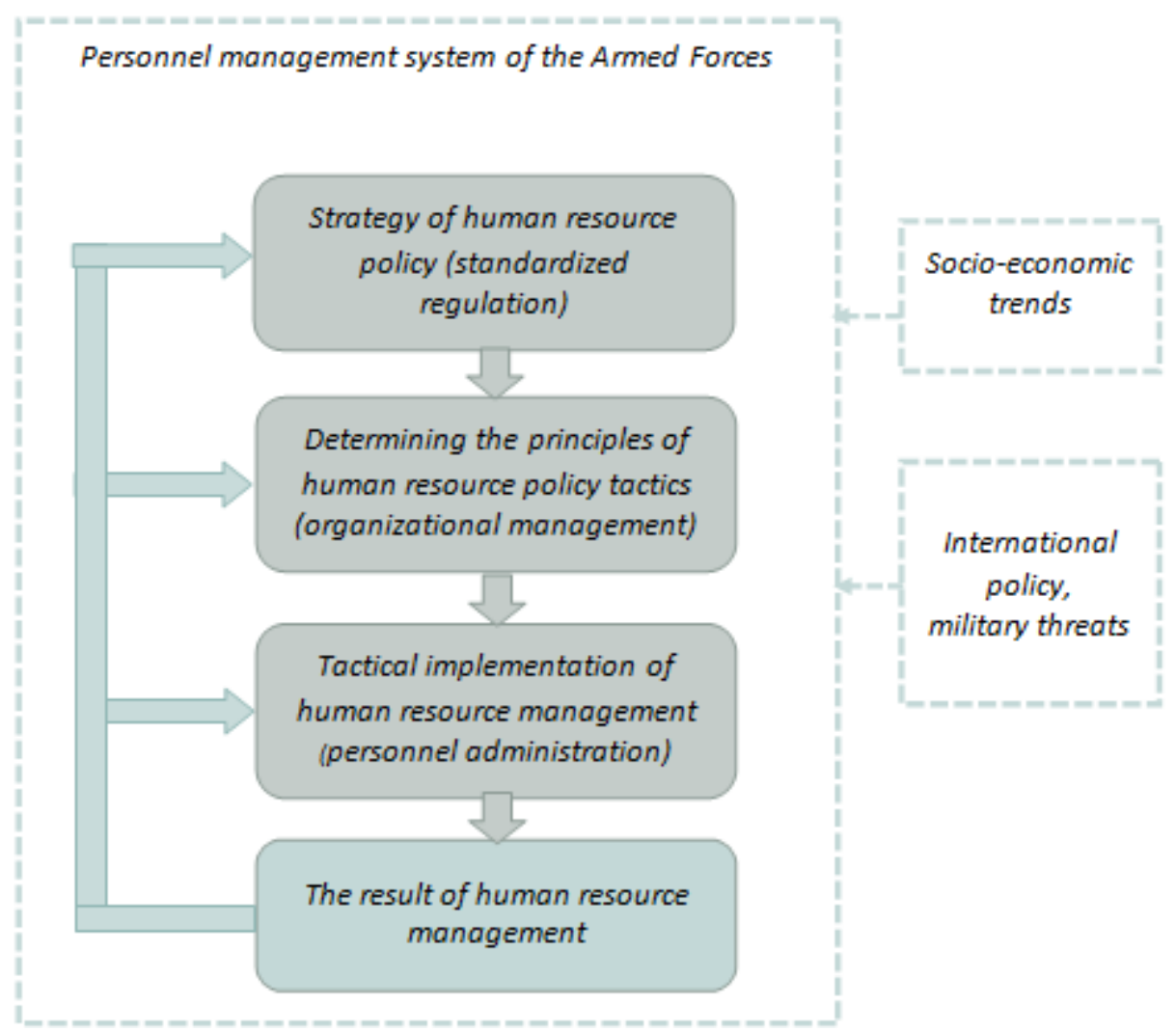

Fig. 1: Features of the personnel management mechanism of the Armed Forces

It is important to have feedback in the system. This means that analysis of personnel administration outcome and evaluation of goals achievement should be carried out. Recommendations on amendments to the state policy on manning of the $\mathrm{AF}$ of Ukraine should be formed basing on the results of such analysis.

The external environment has a significant impact on the human resource management system of the armed forces, in particular, domestic socioeconomic trends, international politics and the presence of external military threats.

Analysis of the implementation of the defense manning reform of the AF of Ukraine showed that, although the normatively defined principles of the new human resource management system generally meet modern international standards, in particular those of NATO member states, their implementation does not lead to expected results.

In our opinion, it occurs in response to insufficiently effective tactical implementation of the basic principles of human resource management and inadequate feedback in the system. In other words, there are implementation gaps at the stage of personnel administration.
According to Semeniy, for the successful construction of a smart defence system, it is necessary to apply a systematic approach to reforming the military sector - a new model of the army (personnel, scheme of interaction and quality of management, technical equipment), development of military-industrial complex following the needs of the new generation. modernization of existing weapons, new high-quality models and their rapid launch in a series), active practical cooperation with foreign partners to gain the necessary best practices and skills to use the latest equipment in an integrated model of modern combat [31].

\subsection{Areas of Improvement}

Therefore, in order to address challenges connected with the implementation of human resource policy in the field of defense, we consider it necessary to focus on the following areas of its improvement:

- Planning of personnel administration. Planning of personnel management should consist of continuous analysis and updating of the projected number of persons recruited and discharged from military service. It concerns more balanced planning of the state order for military specializations in higher educational institutions. 
- Improvement of educational methods in military educational institutions: introduction of innovative methods, update of physical infrastructure, including state of art equipment, simulators, educational literature. It is necessary to take into account a need for instructor education as they provide training and retraining of the military. A serviceman must be not only a professional, but also a person with high moral qualities, who is able to take responsibility for solving complex militaryprofessional tasks, and such qualities must also be nurtured.

- Introduction of individual plans into the educational process / career of a serviceman. As mentioned previously, today one of the principles of the defense reform is the transition from commandand-control methods to more personalized personnel management. As part of this approach, it will be appropriate to develop individual career plans for servicemen.

First of all, vocational guidance should be conducted. It can be carried out in the form of the assessment by an expert commission and through self-evaluation of knowledge, skills and needs of the serviceman in order to offer the desired ways of his/her further professional development. After that an educational /advanced training plan which will allow the serviceman to develop professionally should be drawn.

- Retraining / advanced training. The condition for the development of professionalism of a specialist in any field is the constant improvement of his/her skills. Timely knowledge update is important in rapidly evolving conditions of military affairs, when defense sector of Ukraine develops and adaps to international norms. Today, in-service training is sometimes treated irresponsibly, being considered as unnecessary, but efforts should be taken to support its quality at the appropriate level, and to provide the availability of relevant teaching materials and qualified instructors.

Within the framework of the cooperation program between the AF of Ukraine and the forces of NATO member states, it is necessary to constantly increase the professional level of the personnel of the AF of Ukraine in order to ensure compatibility in joint exercises, certain international security and peacekeeping operations. Cooperation with foreign instructors could facilitate training of specialists in NATO programs. Due to the introduction of NATO standards in the activities of the $\mathrm{AF}$ of Ukraine, the importance of foreign language proficicency by the military should also be noted. Today, foreign language courses do not show desired outcome, which is preconditioned more by a lack of motivation among servicemen than by a low level of intructor qualification. In order to increase motivation, it will be appropriate to introduce additional bonuses to those who prove their foreign language proficiency.

- Improvement of rotation mechanisms. It is important to introduce a system of professional selection, rotation and certification of servicemen (in particular, officers), the introduction of a planned promotion mechanism, the introduction of a rating system for evaluation and promotion. In particular, the prospects of rotating to NATO member countries to share experiences should be considered.

As indicated above, the problem is profanation in the implementation of certain tools of human resourse management, so it is important to control and monitor the quality of their implementation constantly.

In 2021, the analytical department of the public organization "RETURN ALIVE!" (Within the framework of the Initiative for the Development of Analytical Centers in Ukraine, implemented by the International Renaissance Foundation in partnership with the Open Society Initiative for Europe (OSIFE) with the financial support of the Swedish Embassy in Ukraine) a study was prepared. lose qualified personnel. In particular, it was established that such problems as the attitude of the military system, the quality of management and leadership, processes and procedures inherent in the Armed Forces of Ukraine, prevent the entry of new promising personnel into the Armed Forces. Other problems include the results of the study [27]:

1) Insufficient housing. The existing housing stock in the form of barracks, even of an improved type, does not provide servicemen with personal space, while it is one of the greatest requirements for housing. Other problems pointed out by the respondents: insufficient number of official housings, a non-transparent system of obtaining it, regular removal of such housing from the fund owned by the Ministry of Defense.

2) Imbalance of working and personal time. This problem is related to the army's noncompliance with the requirements of the legislation on the standardization of the working day and the inability to plan personal life due to the high intensity of involvement of units in combat training, participation in "Joint Forces Operation", etc. 14 Section 2 The legislation provides for a nonstandard working day for servicemen during their stay on training grounds or in the area of the Joint Forces Operation and an 8-hour working day for servicemen of contract service during their stay in 
the military unit. But in practice, the working day in a military unit often exceeds 8 hours.

3) Bureaucracy in the army. In general, the problem of bureaucracy can be described by the number of documents that servicemen need to keep in command positions. Thus, the platoon commander in the environmental protection zone fills in 13 journals, diagrams, tables, etc., as well as some so-called formalized documents. This leads to the fact that the team devotes up to $90 \%$ of office time to paperwork, while there is almost no staff left.

4) Imbalance in military self-development and career growth. Problems in this area are reduced to the quality of military training in training centres, the content of military service, the circumstances associated with the planning of exercises and the distribution of servicemen in positions. Quite often, respondents noted the unsatisfactory quality of training in training centres. This situation is due to the insufficient practical training of acquired skills, involvement of servicemen in the performance of economic work, low qualification of instructors (sometimes yesterday's conscripts) who have to teach something new, in particular to people with combat experience. One of the biggest stimuli for servicemen is the filling of military service during the stay of units in the military unit. This is since in the military unit the service is largely reduced to the performance of non-military tasks.

5) Financial security plays not the least role in motivating people to work. The problems in this area are that the level of financial support is low given the tasks set before the military, and the system of monetary support does not encourage people to take on additional responsibilities.

6) Quality management and leadership. According to the respondents, the problems with management and leadership in the Armed Forces are an echo of the old conscript army, which was formed on a coercive basis. old approaches to management, such as humiliation, inability to communicate with personnel and superior treatment, are most common among old-school officers without combat experience and so-called military retirees who returned to the Armed Forces after the war in eastern Ukraine and returned en masse with the old approaches.

7) Participation in hostilities. Some servicemen signed a contract with the Armed Forces motivated to fight in eastern Ukraine as part of the Joint Forces. It is important for them to feel involved in the common cause, the liberation of the occupied territories and the protection of relatives.
8) The lack of proper selection for military service is a consequence of the low number of units, due to which the military registration and enlistment offices are subject to mandatory recruitment plans.

According to analysts of the public organization "RETURN ALIVE!", to solve the above problems should be [27]:

i. It is recommended to build and re-equip the existing housing stock (barracks and dormitories) to provide servicemen with the most comfortable personal space. For example, the US Air Force implements the Dorms-4-Airmen concept, where 128 servicemen live in a dormitory in 32 apartments (4 people each). Each has its own room and shower but shares a kitchen and living room with the other three. The issue of service housing in the form of service apartments can be resolved by increasing funding for the construction of such housing and the transition from the model of office housing to the model of staff housing. This will ensure the preservation of the housing stock in the ownership of the Ministry of Defense of Ukraine, as housing will be assigned not to a serviceman, but to a certain position and, accordingly, will be transferred to the position.

According to Deputy Defense Minister Oleksiy Martsenyuk, the Armed Forces of Ukraine have a huge amount of surplus property and land that can be used for investment housing. Currently, the Ministry of Defense together with deputies is preparing a bill that will take into account all the risks of investment construction. According to Martsenyuk: "Ukraine is the only post-Soviet country that buys and builds apartments for the army. Leading countries, especially our NATO partners, have long departed from this type of security, instead of using monetary security. This includes financial leasing, preferential lending, etc." The Ministry of Defense of Ukraine has already prepared a list of land plots for tenders for investment development [30].

ii. Introduce benefits that the military family needs. These could be, for example, subsidized pediatric programs for military families. Families also need to be provided with housing and related infrastructure, such as kindergartens. This will create additional incentives to transport the family to the garrison where the serviceman serves and, consequently, reduce the number of those who are dismissed because the family lives in another locality.

iii. It is necessary to determine what part of the processes can be completely translated into the electronic form or even reconsider their 
feasibility. safety briefings should be conducted annually or once when signing a contract or entering a new position. Accordingly, the Armed Forces of Ukraine have the right to expect that servicemen can understand and follow safety rules after 1-2 briefings. Because in practice military personnel do not always meet these requirements, the introduction of quality selection can solve this problem.

iv. To correct the situation with the quality of training, it is recommended to introduce a mechanism for evaluating instructors and teachers by cadets. This will provide feedback and help change approaches to teaching. It is also important to acquaint candidates for military service with its actual content. In this context, it is correct to introduce the military rank of a conscript in the Armed Forces of Ukraine. He will enter into a probationary contract without completing a full course of military training. This will allow him to decide whether he is ready to be a soldier and the army to make sure that a contract should be signed with this person.

v. Introduce a system of monetary support, which would focus on the market salaries of civilian counterparts in military positions. To do this, it is necessary to introduce a grading system, the essence of which is to determine the value of a position to achieve the goal of the organization and determine the monetary equivalent of such value. Its implementation requires the involvement of civilian HR specialists. Grading will help to avoid the injustice of the current cash security system and will encourage servicemen to grow professionally, as the grading system does not provide for the levelling of the level of cash security with additional payments.

vi. Curricula in military higher education institutions and training centres should be revised and improved. Leadership courses, as well as programs of the humanities (sociology, psychology, ethics) with the appropriate content and quality of teaching, should become a mandatory component of the training of commanders at all levels.

vii. Monitoring should be carried out regularly (monitoring means constant monitoring of certain processes. According to the conclusions of the monitoring results, management decisions are proposed) of the results of leadership courses. The projected effect should be to improve the atmosphere in the units and increase the satisfaction of subordinates with their commanders, and commanders with their subordinates. viii. Soldiers who joined the army from the standpoint of participation in hostilities should be offered such tasks in which they will be maximally realized. One way to help keep these people in the military could be to expand Ukraine's peacekeeping operations and increase participation in military missions around the world.

ix. Full selection for military service in the Armed Forces of Ukraine should be introduced. At the same time, it is necessary to change the approach to determining fitness for health and make a list of diseases that do not actually affect fitness. The purpose of selection should be the gradual emergence of a critical mass of "motivated" servicemen in the units. Their presence in the required number will positively affect the atmosphere in the unit and at the same time will become the standard of behaviour for those who tend to behave like the majority.

As of July 2021, the Ukrainian Parliament has prepared for the second reading - a draft law on amendments to the Law of Ukraine "On social and legal protection of servicemen and members of their families" [29]. In particular, a significant change that many ex-servicemen expect is the retention of soldiers who are entitled to a military pension. They want to secure the right to be on the waiting list in the military unit after receiving discharge from military service until they receive housing or, if they wish, monetary compensation, and in case of disbandment of the unit - in military commissariats and apartment maintenance bodies.

As for various types of military leave, there are also significant positive changes. Legislators plan to expand the types of leaves that are in the legislation for the military. These include annual leave, leave for conscripts and cadets, leave for women servicemen in connection with pregnancy and childbirth, for caring for a child up to the age of three, sick leave and family circumstances. All of them can be provided during the period, especially for the current period.

The drafters of the bill significantly expand the types of leave, including medical leave, additional study leaves, additional leave for combatants and persons with disabilities due to war, additional leave for servicemen participants in the liquidation of the Chernobyl accident category 2, additional leave for servicemen who have children or an adult child with a disability from childhood [28]. 


\section{Improving Training Efficiency}

To achieve continuous improvement in the RC school system, decision makers must be able to continually measure performance and efficiency. An important recommendation from today is the recommendation from the Arroyo Center, which emphasizes that the army should implement a system of quantitative monitoring in order to establish relevant performance indicators, goals, and tasks for systematic monitoring of quality and level of progress. As a result, it will be possible to focus more on the current challenges that may occur when achieving results and identify appropriate solutions. [19].

An illustrative example is the case of the Australian Army, which in the recent past has adopted an updated system of physical employment standard (PES) assessments for active-duty servicemen, which has a direct correlation with the physical capabilities required to perform military tasks. Yes, today, muscle strength and critical physical ability are a must-assess performance [20].

According to Army researcher Dr. Alec Koppel (US Army Combat Capabilities Development Command, now known as DEVCOM, Army Research Laboratory), these training components help autonomous agents to reason and adapt to changing conditions on the battlefield. According to the expert, the key mechanism for adaptation and redevelopment consists of a policy based on reinforcement. Researcher Koppel believes that the vector of increasing this policy may be the further implementation of the operational concept of MDO in reality [21].

A clear example of the above context is the situation with the United States Air Force (USAF), which noted that their fighter pilots do not currently have sufficient access to airspace training grounds, threat emitters, targets and electronic support capabilities capable of represent advanced potential adversaries. The answer to this challenge was the decision of the US Air Force, which is already developing a plan to modernize certain ranges with these capabilities [22].

For individual Army schools to plan and schedule training more efficiently, accurate and timely estimates of student enrollments are needed. One way to accomplish this is to increase the flexibility of the signup system by, for example, earlier reassignment of training seats from units not using them to others that could [23].

Mcardle, Kehr and Colabatistto emphasize, the increased employment of a synthetic environment may have broader strategic warfighting benefits. Indeed, while exercises can serve multiple purposes in times of peace and war - such as demonstrating resolve, reducing tensions, or deterrence - they can also, in certain circumstances, alert an adversary to emerging innovative technologies, concepts of operations, or more tailored force structures [24]. An example that determines the expert opinion from the point of view of the Ukrainian present is the reaction of the current Russian authorities to largescale military exercises of NATO and Ukraine: DEFENDER-Europe 21 and Sea Breeze-2021. Thus, according to Deputy Foreign Minister A. Rudenko, "Moscow takes into account the rhetoric of the Ukrainian authorities regarding a possible military confrontation and is aware of Kyiv's military preparations with the help of its Western partners." However, he did not rule out the possibility of a "military scenario in the development of Russian-Ukrainian relations," and also said that "the Russian military budget already has a corresponding item of expenditure" [34].

According to McGee, "We must be prepared to fight large-scale combat operations in the future against near-equal threats. That is why we need to expand our forces as much as possible, and one of our real strengths is our people". In the context of the topic of the scientific article, this conclusion seems to us quite relevant and necessary in the context of reforming the Ukrainian army, which after the beginning of the Russian aggression in 2014 , is actively renewed and becomes a soldiercentric [25].

We agree that process changes are needed to address the existing problems. Comprehensive changes must affect both the strategic and operational levels. Soldiers and military personnel must learn new complex processes. Ukraine as a state should not demand high-quality performance of tasks from a serviceman without providing him with all the necessary material and intangible resources. At the same time, the state should not turn a serviceman into another beneficiary. It should assess the contribution of each serviceman to the achievement of the goals of the Armed Forces of Ukraine and provide him with decent compensation [27].

\section{Conclusions and Perspectives of Further Research}

Further implementation of defense reform in terms of human resourse policy transformation requires increased control over the quality of mechanisms for human resourse management. The analysis showed that there are risks of insufficiently responsible 
attitude to personnel management, which is manifested in biased performance assessment, lack of rotation, low advanced training outcome.

These challenges can be solved by strengthening the monitoring of human resourse services that interact directly with the military. The servicemen training system, the quality of the educational process in military educational institutions, and the system of advanced training also require improvement. It is necessary to use the tool of individual career plans for servicemen, which would include subsystems of career guidance, evaluation and self-evaluation, determination of professional skills and abilities, training / retraining / advanced training planning and forecasting further career development.

This article describes ways to improve management such as planning of personnel administration, improvement of educational methods in military educational institutions, introduction of individual plans into the educational process and retraining / advanced training of personnel.

The army and Ukraine in general need to work to strengthen human capital. Ukraine needs new military specialists and civil servants who have qualitatively new knowledge who are ready to combine this knowledge with the unique combat experience they have gained while defending Ukraine. New professionals who will receive high positions must be able to work in a new professional cultural environment. A new culture is an opportunity for a different organization of work, where authority is delegated, where there is collective thinking, decision-making, where there is the ability to apply the latest technologies and digital networks and where there is the ability to work in a multinational environment. a multinational group implements such a decision [26].

Improving the personnel management system will facilitate manning of the AF of Ukraine due to the implementation of effective military career management mechanisms, a transparent selection system, further implementation of automated personnel accounting and management systems. Further research within the framework of the identified issues should be aimed at developing specific tools for human resource policy and human resource management technology in the AF of Ukraine.

\section{References:}

[1] Bielileskov M. (2020). The main problem of our army is limited resources. Official website of the Ministry of Defense of Ukraine. Retrieved from: https://www.mil.gov.ua/ministry/zmi-pronas/2019/12/16/osnovna-problema-nashogovijska- $\%$ E2\%80\%93-obmezhenist-resursiv$\%$ E2\%88\%92-mikola-beleskov/ .

[2] On the Decision of the National Security and Defense Council of Ukraine as of May 20, 2016 «On the Strategic Defense Bulletin of Ukraine»: Decree of the President of Ukraine №240/2016 as of June 6, 20016. [cit. 2020-1006.] Retrieved from: https://www.president.gov.ua/documents/24020 16-20137

[3] Patrichi M. E. (2015). General Military Human Resource Management and Special Forces Human Recourse management. Journal of Defense Resources Management, Vol. 6, No. 2, pp.75-82. Retrieved from: http://journal.dresmara.ro/issues/volume6_issue 2/09_patrichi.pdf

[4] Krasota, I., Trakaliuk, O., Shtanko V. (2018). Experience of reforming the human resource management system in the Armed Forces of Ukraine. Visnyk Kyyivskoho nacionalnoho universytetu imeni Tarasa Shevchenka. Vijskovo-specialni nauky, No. 3, pp. 53-57. Retrieved from: http://nbuv.gov.ua/UJRN/VKNU_vsn_2018_3_ 16

[5] Narang, G. S. (2016). Relevance of Best Human Resource Practices for the Armed Forces. Arabian Journal of Business and ar A Management Review, No. 6. pp. 232-234. DOI: $10.4172 / 2223-5833.1000232$.

[6] Goede, P. (2020). Strategic Strengthening of the Armed Forces. Security in an Interconnected World, Chapter 6, pp.119-144. DOI: 10.1007/978-3-030-37606-2_6.

[7] Medvid A. P., Polovinkin I. M. (2010). Human resource management system in the Armed Forces of Ukraine: features of development. Kyiv, p. 97 Retreived from: http://library.iducz.dsns.gov.ua/weblib/books/ Medvid A P /Monografy.pdf

[8] Hrinenko O. I., Kutovyi O. P., Shaptalenko M. I. (2017). To Mobilize the State, Oboronnyi visnuk, No. 4, p. 24-28.

[9] Koval O. (2017). Improving the state human resourse policy in the Armed Forces of Ukraine. Public Administration and Local Government, No. 4, pp. 163-173. Retreived from: 
http://www.dridu.dp.ua/vidavnictvo/2017/2017 04(35)/24.pdf

[10] Gozuvatenko, G. (2016). Enchancement of the military training and career growth system of the Armed Forces of Ukraine, taking into account the experience of leading countries, Skhid, No. 6, pp. 56-59. Retrieved from: http://nbuv.gov.ua/UJRN/Skhid_2016_6_10

[11] 2020 Military Strength Ranking. Retrieved from:

https://www.globalfirepower.com/countrieslisting.asp

[12] On State budget of Ukraine for 2020: The Law of Ukraine as of November 14, 2019 No. 294IX. UPD: 2020.18.06. Retrieved from: https://zakon.rada.gov.ua/go/294-20

[13] The Vision of the General Staff of the Armed Forces of Ukraine for the development of the Armed Forces of Ukraine for the next 10 years. Official website of the Ministry of Defense of Ukraine. Retrieved from: https://www.mil.gov.ua/news/2020/01/11/viziy a-generalnogo-shtabu-zs-ukraini-shhodorozvitku-zbrojnih-sil-ukraini-na-najblizhchi-10rokiv

[14] LeMoyne J. (2004). How the Army Runs, Chapter 13, Military Human Resource Management. Retrieved from: https://www.globalsecurity.org/military/library/ report/2003/htar-chapter13.pdf

[15] Stanit A., Rizescu M. (2012). Human Resources Management Efficiency In The Military Organization, Revista Economica, Lucian Blaga University of Sibiu, Faculty of Economic Sciences, Vol. 0(2), pp. 364-368.

[16] Patrichi M. E. (2015). General military human resourse management and special forces human resourse management. A comparative outlook. Journal of Defense Resources Management, No. 6 (2), pp. 57-74.

[17] Leonard A. H. (2017). Effective, Legitimate, Secure: Insights for Defense Institution Building. Chapter 7.

[18] Nekoranec Y., Revayova E. (2020) Strategic management of human resource and the Slovak armed forces, p. 55.

[19] Winkler J. D., Shanley M. G., Schank J. F., Crowley J. C., Mattock M. G., Green D., Madison R., McDonald L. L., Steinberg P. S. (1999). Improving Performance and Efficiency in the Total Army School System. Santa Monica, CA: RAND Corporation. Retrieved from:

https://www.rand.org/pubs/research_briefs/RB 3015.html
[20] Drain J. R., Sampson J. A., Billing, D. C., Burley S. D., Linnane D. M., Groeller H. (2015). The Effectiveness of Basic Military Training To Improve Functional Lifting Strength in New Recruits. Journal of strength and conditioning research / National Strength \& Conditioning Association. 29 Suppl 11. S173-S177. 10.1519/JSC.0000000000001072

[21] U.S. Army DEVCOM Army Research Laboratory Public Affairs. Army research leads to more effective training model for robots. December 29, 2020

[22] Bradley D., Mills P., Narayanan A., Gold D., Wirth A. J., Ausink J. A., Bennett B. E., McGarvey R. G., Ali R., Syme J., Williams R. H. (2021). Fighter Basing Options to Improve Access to Advanced Training Ranges. Santa Monica, CA: RAND Corporation. Retrieved from:

https://www.rand.org/pubs/research_reports/R RA169-1.html

[23] Shanley M. G., Winkler J.D. (1999). Improving Training Efficiency: Lessons from the Total Army School System. Santa Monica, CA: RAND Corporation. Retrieved from: https://www.rand.org/pubs/research briefs/RB 3008.html.

[24] Mcardle J., Kehr T., Colabatistto G. (2020). Pandemics and the future of military training. Texas national security review. Retrieved from: https://warontherocks.com/2020/03/pandemicsand-the-future-of-military-training/

[25] Brading T. (2020). 2020 banner year for Army talent management. Army News Service. Retrieved from: https://www.army.mil/article/241759/2020 ban ner_year_for_army talent management_says director

[26] Komisarova O. (2021). How close the Ukrainian army is to NATO standards. The Deputy Minister of Defense is responsible. Retrieved from: https://suspilne.media/145005naskilki-ukrainska-armia-nablizilasa-dostandartiv-nato-vidovidae-zastupnik-ministraoboroni/

[27] The International Renaissance Foundation. (2021). Why are servicemen discharged from the army? Public version. Retrieved from: https://www.irf.ua/wpcontent/uploads/2021/06/zvit-ua-digital.pdf

[28] Berezyns'kyy I. (2021). Improving military social standards: what they plan to change. Retrieved from: https://armyinform.com.ua/2021/05/pokrashhen nya-soczialnyh-standartiv-vijskovyh-shhoplanuyut-zminyty/ 
[29] On Social and Legal Protection of Servicemen and Members of Their Families: Draft Law on Amendments to the Law of Ukraine as of Octouber 29, 2019 No. 2343. UPD: 02.02.2021. Retrieved from: http://w1.c1.rada.gov.ua/pls/zweb2/webproc4 1 ?pf3511 $=67225$

[30] Center for Public Monitoring and Control. (2020). An army with a human face: what's new in 2020? Retrieved from: https://naglyad.org/uk/2020/03/10/armiya-zlyudskim-oblichchyam-shho-novogo-u-2020$\underline{\mathrm{mu} /}$

[31] Semeniy O. (2016). Transition security. How to counter aggression with limited resources. Retrieved from: https://www.eurointegration.com.ua/articles/20 16/12/26/7058853/

[32] Hetmanchuk A., Fakhurdinova M. (2021). Ukraine and NATO standards: what has been done during Zelensky's presidency? Retrieved from: $\quad$ http://neweurope.org.ua/wpcontent/uploads/2021/04/FINAL_UkraineNATO Zel ukr.pdf

[33] The International Renaissance Foundation. (2021). Why are servicemen discharged from the army? Retrieved from: https://www.irf.ua/chomuvijskovosluzhbovczi-zvilnyayutsya-z-armiyi/

[34] Sichen I. (2021). Autumn of Angst. Russia's Reaction to Ukraine's Military Exercises. Borysfen Intel. Retrieved from: https://bintel.org.ua/en/analytics/spekotna-osin2021-roku-reakciya-rosii-na-vijskovinavchannya-ukrainy/
Contribution of Individual Authors to the Creation of a Scientific Article (Ghostwriting Policy)

Vita Halushka wrote $30 \%$ of the paper Hryhorii Tikhonov wrote $15 \%$ of the paper Yurii Mykolenko wrote 15\% of the paper Liudmyla Drok wrote $25 \%$ of the paper Ivan Tikhonov wrote $15 \%$ of the paper

\section{Sources of Funding for Research Presented in a Scientific Article or Scientific Article Itself}

There was no additional funding.

\section{Creative Commons Attribution License 4.0 (Attribution 4.0 International, CC BY 4.0)}

This article is published under the terms of the Creative Commons Attribution License 4.0 https://creativecommons.org/licenses/by/4.0/deed.en US 